\title{
A CAIXA ESQUECIDA DA INFÂNCIA DE COETZEE
}

\section{THE FORGOTTEN COETZEE BOYHOOD BOX}

\author{
André Natã Mello Botton ${ }^{1}$
}

\begin{abstract}
RESUMO: O romance autobiográfico Infância, de J. M. Coetzee, apresenta-nos um narrador estruturado a partir de uma terceira pessoa; em vários momentos da narrativa está completamente alheio e "fora" dos fatos narrados, além de que a criança é vista sobre a ótica do narrador adulto. Da mesma forma, em algumas fotos tiradas pelo autor durante 1955 e 1956, percebemos semelhanças entre o narrador textual de Infância e o narrador imagético do acervo fotográfico. Com isso, pretendemos ao longo deste ensaio fazer uma aproximação entre os dois narradores, acionando conceitos de "narrador", "memória" e "fotografia" para perceber como os fatos narrados são apresentados ao leitor. Ao mesmo tempo, pretendemos avaliar, à luz do estudo de Aleida Assmann (2011), a importância da caixa com negativos de fotografias tiradas por J. M. Coetzee e que também retratam momentos de sua infância.
\end{abstract}

PALAVRAS-CHAVE: autobiografia; memória; fotografia; Infância.

ABSTRACT: The autobiographical novel Boyhood by J. M. Coetzee presents us a narrator structured from a third person; at various moments in the narrative, he is completely unaware of and "out of" the narrated facts, and the boy is viewed from the perspective of the adult narrator. Likewise, in some photos taken by the author during 1955 and 1956, we noticed similarities between the textual narrator of Boyhood and the imagetic narrator of the photographic collection. With this, we intend throughout this essay to make an approximation between both narrators, adding concepts of "narrator", "memory" and "photography" to understand how the narrated facts are presented to the reader. At the same time, we intend to evaluate, in the light of the study by Aleida Assmann (2011), the importance of the box with negatives of photographs taken by J. M. Coetzee and that also portray moments of his childhood.

KEYWORDS: autobiography; memory; photography; Boyhood.

\section{Os arquivos da memória}

Em 2014, depois de estar morando há muito tempo na Austrália, John Maxwell Coetzee vende seu apartamento na Cidade do Cabo, na África do Sul. No entanto, vasculhando pela casa, um pesquisador encontrou uma caixa deixada num dos cantos da residência e descobriu uma série

\footnotetext{
${ }^{1}$ Doutorando em Linguística e Letras pela Pontifícia Universidade Católica do Rio Grande do Sul.
} 
de negativos de fotos tiradas durante os anos de 1955 e 1956 (quando Coetzee tinha entre 15 e 16 anos), nunca antes mostradas pelo ganhador do Nobel de Literatura ${ }^{2}$. As imagens retratam cenas do cotidiano capturadas pela lente do jovem Coetzee e que ao mesmo tempo contribuem para as descrições que estão contidas nos seus três livros autobiográficos: Infância (1998), Juventude (2002) e Verão (2009). As fotografias apresentam a perspectiva do então adolescente para a sua família (pai, mãe, irmão e tia), para o cotidiano na escola St. Joseph's Marist College, bem como a imagem da fazenda Voëlfontein, em Karoo, e dos trabalhadores desse local, Ros e Freek. As imagens tornaram-se uma exposição no Irma Stern Museum, na Cidade do Cabo, durante o mês de janeiro de 2018.

$\mathrm{O}$ esquecimento das imagens em um canto do apartamento vendido pelo autor nos possibilita questionar a relação entre o "recordar" e o "esquecer", pois, "o objeto da recordação está marcado pelo esquecimento, e o esquecimento torna-se um aspecto indelével do recordar; a recordação traz em si vestígios do esquecimento" (ASSMANN, 2011, p. 107). Aleida Assmann, ao atualizar a teoria de John Locke a respeito da memória, introduz o conceito de "esquecimento" enquanto relação indissociável da memória em si. Em outras palavras, o recordar está interpenetrado pelo apagamento constante e indissociável das experiências dos sentidos e das noções de tempo, de modo que a memória não pode ser vista como um recipiente fechado, mas está suscetível a acontecimentos externos - sejam eles sensoriais ou emocionais (ASSMANN, 2011).

Dessa forma, aquela caixa encontrada num apartamento vendido por J. M. Coetzee, torna-se uma caixa mnemônica na medida em que possibilita pensar a "concretização espacial da recordação" (ASSMANN, 2011, p. 125). Diferentemente dos três exemplos citados pela autora alemã, em Espaços da recordação: formas e transformações da memória cultural, a caixa de fotografias de Coetzee não é uma "arca de valor" - conforme a concepção cristã de Hugo de São Vítor - também não é "a caixinha de Dario" - pois não confronta aspectos da tradição e formação, conforme o texto de Heinrich Heine -, e, por fim, não é "o caixote cruel" - uma vez que não se torna um peso opressor da vida da mesma forma que o é para a personagem de E. M. Forster. Ao contrário, a caixa de Coetzee torna-se símbolo de todas aquelas memórias e imagens

\footnotetext{
${ }^{2}$ Informações retiradas do site: https://www.nytimes.com/2018/01/16/arts/design/coetzee-photographs.html acesso em jun. de 2019.
} 
que foram esquecidas, mas mais do tudo que querem ser esquecidas e deixadas no passado abandonada em algum canto qualquer da memória, ou mesmo de um apartamento vendido. A falta de desejo em levar consigo os negativos das imagens demonstra a vontade em abandonar as recordações num canto qualquer da memória e deixá-las lá. No entanto, o descaso para com essa caixa torna-se índice de questões que nos surgem, pois, o autor, em alguma medida, em seu livro Infância, relembra momentos que estão registrados pela lente de sua câmera. Por que, então, esquecer essas fotos se ele depois contará fatos relativos a elas e a sua infância? Que relação pode ser feita a partir das três outras caixas mnemônicas que Aleida Assmann (2011) retoma em seu texto? Seria essa uma quarta caixa, a caixa esquecida ou abandonada? Antes da análise do que fora esquecido ou abandonado, achamos necessário trazer à presente discussão o conceito de "memória" que nos possibilita questionar essa relação entre esquecimento e abandono.

Na primeira parte de A memória, a história, o esquecimento, Paul Ricoeur (2007) faz uma análise do conceito de "memória" a partir da fenomenologia, retomando, primeiramente, o pensamento platônico e aristotélico para, na sequência, construir o seu:

O primeiro [Platão], centrado no tema da eikõn, fala de representação presente de uma coisa ausente; ele advoga implicitamente o envolvimento da problemática da memória pela da imaginação. O segundo [Aristóteles], centrado no tema da representação de uma coisa anteriormente percebida, adquirida ou aprendida, preconiza a inclusão da problemática da imagem na lembrança. (RICOEUR, 2007, p. 27).

Os dois filósofos gregos partem da ideia da representação para desenvolverem o seu pensamento acerca da memória. Os desdobramentos que fazem sobre o mesmo conceito se dão de modos distintos: Platão percebe que a memória produz duas "marcas" no homem, a cópia (eikõn) e o simulacro (phantasma), sendo que as duas se perfazem enquanto uma "presença do ausente". A vivência do sujeito produz "rastros" em sua memória e que ficam "guardados" em si enquanto cópia e simulacro, sendo que essas imagens são relembradas quando há um estímulo envolvendo sensações e/ou reflexões. Por outro lado, Aristóteles percebe a recordação da memória de modo mais ativo, enquanto busca por algo. Para o estagirita, em um primeiro momento, a memória se dá como "afecção", uma mudança no modo de ser, pois a "coisa" lembrada é um fenômeno presente na alma do homem. Uma vez que aquilo é lembrado, o fenômeno da memória estaria no passado, em relação "com o futuro da conjetura e da espera com 
o presente da sensação (ou percepção) que impõe essa caracterização primordial" (RICOEUR, 2007, p. 35). A partir do pensamento aristotélico, Paul Ricoeur consegue relacionar o seu conceito de "tempo" para posteriormente desenvolver outros estudos relacionados a respeito desse fenômeno ${ }^{3}$. Por esse caminho, o ponto em que ambos os filósofos gregos possuem em comum é quanto ao estímulo externo e à semelhança interna quando a memória é presentificada, sendo que para Aristóteles a busca da recordação na memória possui uma distinção clara entre mneme (lembrança, memória-paixão, evocação simples, recordação instantânea) e anamnesis (recordação, recordação-ação, esforço de recordação, recordação laboriosa), enquanto características dessa procura. Por fim, o aluno de Platão destaca que o ato de recordação acontece em uma mudança, quando do movimento temporal, ou seja, é nos movimentos próprios do tempo que a busca da recordação (anamnesis) possibilita a escrita. Uma vez que o esquecimento está relacionado à memória, o ato de escrever uma recordação torna-se um movimento temporal: em que é trazido ao presente algo que está no passado, para registrá-lo a um futuro, conferindo materialidade própria ao ato. Para Ricoeur (2007), "o suporte da escrita confere materialidade aos rastros conservados, reanimados e novamente enriquecidos por depósitos inéditos. Assim, faz-se provisão de lembranças para os dias vindouros, para o tempo dedicado às lembranças” (p. 56).

Nesse constante devir da memória, no entremeio próprio dela, a imaginação torna-se o que preenche ou liga os "locais" que a memória esqueceu. $\mathrm{O}$ ato da recordação estaria dividido em: perceber algo, lembrá-lo e ficcionalizá-lo. "Um limiar de inatualidade é transposto entre lembrança e ficção. A fenomenologia da lembrança deve, então, liberar-se da tutela da fantasia, do fantástico, marcado pelo selo da inatualidade, da neutralidade” (RICOEUR, 2007, p. 65). A lembrança, com isso, torna-se modificação específica da apresentação, pois distingue a reprodução da produção, visto que, faz parte do "mundo da experiência" e não dos "mundos da fantasia".

Ainda sobre a perspectiva do tempo acionada por Paul Ricoeur, faz-se necessário destacar que "reconhecemos a lembrança presente como sendo a mesma e a impressão primeira visada como sendo outra" (2007, p. 56). Se a memória é do passado, e o ato de recordar é do presente, é

\footnotetext{
${ }^{3}$ Neste estudo, não nos cabe fazer maiores digressões sobre o assunto, apenas destacamos aqui o importante estudo de Paul Ricoeur, Tempo e narrativa publicado em 1983, em que o autor abordará o conceito de "tempo" - a partir da sua leitura de Aristóteles - em relação especificamente à narrativa.
} 
impossível que a memória consiga em sua busca trazer ao presente exatamente tudo o que aconteceu ou o que vivenciou num tempo distante. A (re)apresentação de uma lembrança envolve mudança e movimentos intrínsecos à própria reflexão, além de sentimentos e paixões que estão no mesmo plano da memória, enquanto faculdade da mente:

Assim, a memória corporal é povoada de lembranças afetadas por diferentes graus de distanciamento temporal: a própria extensão do lapso de tempo decorrido pode ser percebida, sentida, na forma da saudade, da nostalgia. O momento do despertar, tão magnificamente descrito por Proust no início da Busca..., é particularmente propício ao retorno das coisas e dos seres ao lugar que a vigília lhes atribuíra no espaço e no tempo. O momento da recordação é então o do reconhecimento. Esse momento, por sua vez, pode percorrer todos os graus da rememoração tácita à memória declarativa, mais uma vez pronta para a narração. (RICOEUR, 2007, p. 57).

O momento da escrita do livro Infância torna-se completamente oposto ao que acontece em relação às fotografias. Duas ações são percebidas: na narrativa literária o autor quer recordar e esquecer, já em relação às fotografias, o fotógrafo simplesmente as esquece. O lapso de tempo entre aquilo que é contado em ambos os casos é relativizado pela mudança de atitude, claramente evidenciado pelo narrador extradiegético, ponto em comum nos dois casos. No entanto, o narrador das imagens é um adolescente que já demonstra sua forma de narrar evidenciada posteriormente no romance autobiográfico. Além disso, nas imagens esquecidas no apartamento, é unicamente o sentido que o olho dá a uma determinada realidade capturada através da lente da câmera que narra os fatos contados:

Com a fotografia, a mão foi desencarregada, no processo de reprodução de imagens, pela primeira vez, das mais importantes incumbências artísticas, que a partir de então cabiam unicamente ao olho. Como o olho apreende mais rápido que a mão desenha, o processo de reprodução de imagem foi acelerado tão gigantescamente que pôde manter o passo com a fala. (BENJAMIN, 2014, p. 15).

Walter Benjamin, em A obra de arte na época de sua reprodutibilidade técnica, já apontava para a relação essencial que o olho, enquanto sentido primeiro, possui na obra de arte moderna - tanto a fotografia quanto o cinema. O que Coetzee captura em suas fotografias nada mais é que a realização concreta de um sentido apenas, enquanto que em seus livros autobiográficos o autor relativiza outros sentidos que vêm à memória no momento da recordação: 
Na manhã seguinte, uma hora antes de o sol nascer, ele acorda com o ruído de cascos quando as primeiras tropas de carneiros passam perto da casa a caminho dos currais, ao lado da casa de tosquia. A casa começa a despertar. Há movimento na cozinha e o cheiro de café. À primeira luz ele está lá fora, vestido, excitado demais para comer. (COETZEE, 2010, p. 86).

O trecho acima reúne em si sentidos que são intrínsecos à recordação própria que a memória presentifica (RICOEUR, 2007): audição e olfato. No entanto, ao mesmo tempo, através da narração, é criada também uma imagem: a da confluência da luz nascente do sol na casa da fazenda. Todavia, o artista "pode, por exemplo, na fotografia, acentuar aspectos do original acessíveis somente à lente - ajustável e capaz de escolher arbitrariamente seu ponto de vista -, mas não ao olho humano" (BENJAMIN, 2014, p. 19). A escolha por determinados pontos de vista ou mesmo de quem é fotografado, pode nos levar a questionar o porquê das escolhas feitas por Coetzee naquele instante da captura da imagem. Ou mesmo, numa acepção maior, tentar desvendar os motivos por trás daquele registro. Nesse instante, o livro Infância nos dá indícios das escolhas tomadas pelo jovem fotógrafo e que tentaremos estabelecer na sequência deste ensaio, uma relação entre o texto imagético com o literário.

\section{A captura da memória}

Segundo a concepção de uma "autoficção biográfica", "o escritor continua sendo o herói de sua história, o pivô em torno do qual a matéria narrativa se ordena, mas fabula sua existência a partir de dados reais, permanece mais próximo da verossimilhança e atribui a seu texto uma verdade ao menos subjetiva ou até mais que isso" (COLONNA, 2014, p. 44). Essa concepção acerca da narrativa nos permite aproximar o texto Infância do conceito explicitado acima. No entanto, Cristovão Tezza define o romance da seguinte forma:

"Infância" é uma investigação ficcional sobre esse período difuso em que começamos a nos reconhecer. Seu realismo sente e avalia instintivamente o peso relativo das coisas concretas que dizem quem nós somos: a mãe, o pai, a casa, a terra, os vizinhos, os parentes, as línguas, a escola, os jogos, e a angustiante relação entre essas variáveis agressivas, do meio das quais somos obrigados a emergir como alguém distinto. Do ponto de vista técnico, Coetzee só fala dele próprio na terceira pessoa, como de um estranho a ser decifrado.

\footnotetext{
4 Este trecho assim como os próximos que serão citados do texto de Cristovão Tezza estão disponíveis em: http://substantivoplural.com.br/tezza-escreve-sobre-a-trilogia-de-coetzee/ Acesso em jun. de 2019.
} 
É essa investigação que o narrador constrói na sua narrativa e que podemos perceber nas imagens encontradas em seu apartamento. Como, por exemplo, na imagem e no texto abaixo:

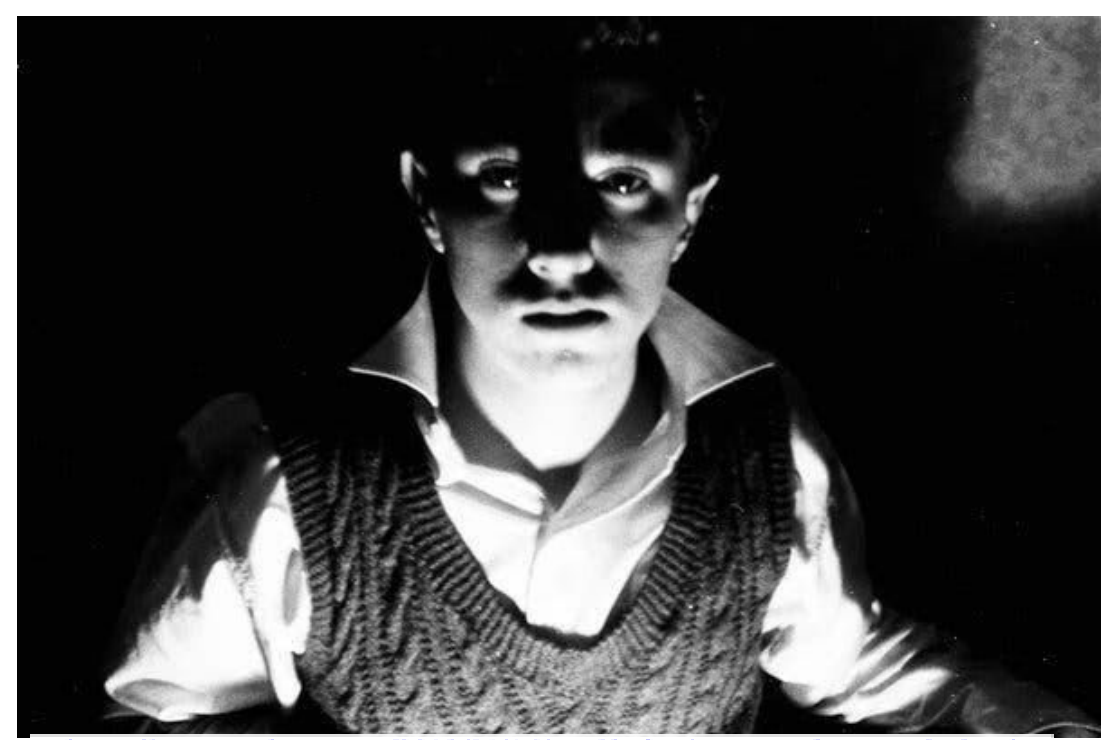

hitps://www nytimes, com/2018/01/6/arts/design/coetzec-photographs, html

Às vezes a tristeza se dissipa. O céu, que costuma pairar fechado sobre sua cabeça, não perto o suficiente para que possa tocá-lo, mas tampouco muito distante, abre uma fresta, e, durante um instante, ele pode ver o mundo como realmente é. Vê a si mesmo de camisa branca com mangas enroladas, a calça curta que quase não serve mais: não uma criança, não o que um transeunte chamaria de criança, está crescido demais para isso, crescido demais para essa desculpa, mas ainda tão idiota e fechado em si mesmo quanto uma criança: infantil, tolo, ignorante, retardado. [...] O céu se abre, e ele vê o mundo como é; depois, quando o céu se fecha, volta a ser ele mesmo vivendo a única história que admite, a sua própria história. (COETZEE, 2010, p. 146).

$\mathrm{Na}$ imagem e no trecho percebemos quem é essa personagem, a descrição no romance coincide com a fotografia do jovem John Maxwell Coetzee. Mas a coincidência não se dá apenas nas roupas, mas o olhar do fotógrafo - assim como o do narrador do texto literário - vem de fora, contudo, somos olhados duramente pelo jovem da fotografia que nos encara firmemente. Já a incidência da luz na fotografia vem de baixo, iluminando as partes do corpo que the interessam e focalizando boca, nariz, olhos e orelhas. Diferentemente do trecho destacado, o céu não se abriu, não há uma luz que vem de cima. Poderíamos dizer que na fotografia ele está vivendo a única história que admite, a sua. Conforme Tezza, "é quase que um olhar de laboratório, e, como tal, busca a exata percepção da lâmina submetida à lente do seu olhar. Sua ficção é cartesiana - mas a 
limpidez lógica de seu olhar se cruza impotente com a exasperante falência dos sentidos para dar conta da realidade”. A realidade presente na ficção e a realidade expressa nas fotografias constituem o olhar em que "o autor modela sua imagem literária e a esculpe com uma liberdade que a literatura íntima, ligada ao postulado de sinceridade estabelecido por Rousseau e prolongado por Leiris, não permitia" (COLONNA, 2014, p. 45-46). O narrador tanto literário quanto imagético conduz o olhar que o leitor terá para as fotos assim como para a diegese. Mais uma vez, esse olhar é cartesiano, próprio da formação de matemático do escritor:

Ele conhece Voëlfontein melhor no verão, quando se estende achatada sob a luz uniforme e cegante que cai do céu. Mas Voëlfontein também tem seus mistérios, que pertencem não à noite e à sombra, mas às tardes quentes, quando as miragens dançam no horizonte e o próprio ar canta em seus ouvidos. Então, quando todos estão cochilando, solapados pelo calor, ele pode sair de casa na ponta dos pés e subir na colina até o labirinto de currais cercados de pedra dos velhos tempos, quando milhares de carneiros eram trazidos das savanas para ser contados, tosados ou tratados. (COETZEE, 2010, p. $85)$.

A imagem da fazenda apresenta dentro do romance uma implicação mais sentimental e de pertencimento. É lá que o jovem gosta de estar, ele se sente como filho daquele chão e sabe-se pertencente àquele lugar:

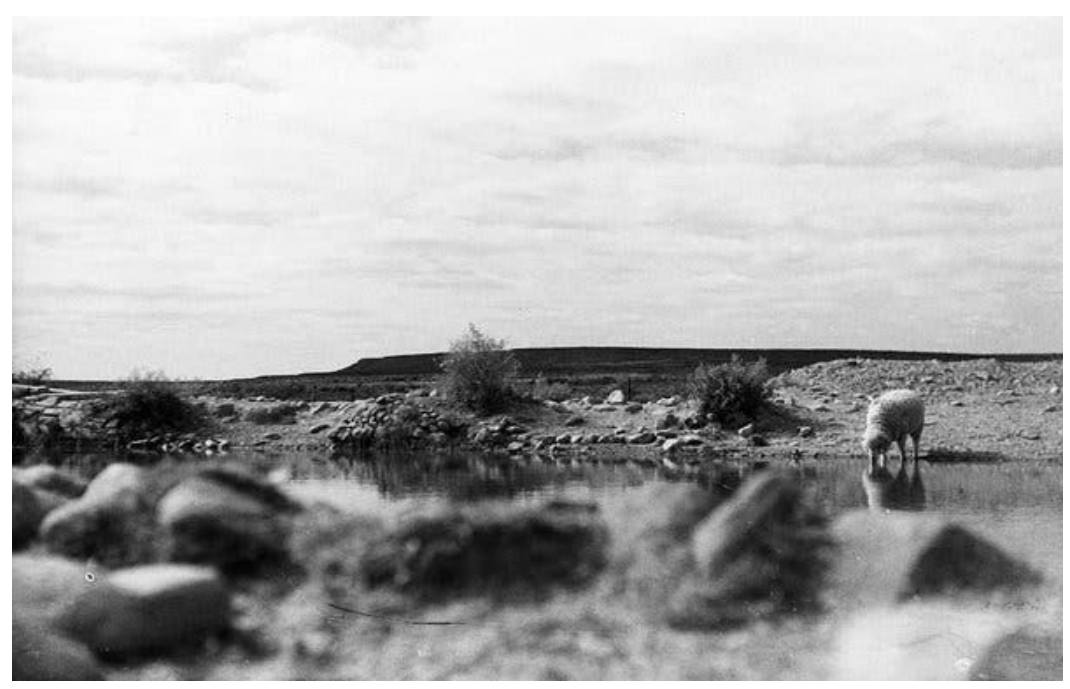

htps:/www.nytimes.com/2018/01/16/arts/design/coetzee-photographs.html

A fazenda pertence a mim. A fazenda nunca pertencerá a ele, ele nunca passará de um visitante: isso ele aceita. [...] Pertenço à fazenda: é o máximo que ele pode ir, mesmo bem no fundo do seu coração. [...] A fazenda é maior que qualquer um deles. A fazenda existe da eternidade para a eternidade. (COETZEE, 2010, p. 89, grifos do autor). 
É o espaço da infância presentificada com apreço e com carinho pelo narrador adulto que nos surge. Tanto neste trecho quanto na fotografia da fazenda, o que predomina, mais uma vez, é o olhar preeminente dos aspectos externos: as colinas, o rio, o carneiro que bebe água, as sombras achatadas pela luz solar do verão. Todo esse cenário arquivado na fotografia e na obra literária compõe as memórias de uma infância alegre e, neste caso, distante da mãe - pois a fazenda pertence à família do pai, e ela não ia junto nessa viagem. A grandeza da fazenda faz com que Coetzee pertença àquele local - o material se sobrepõe ao subjetivo numa possibilidade quase absurda da total abnegação do "eu" -, uma vez que é nesse espaço que ele se sente filho. "Ele tem duas mães. Nasceu duas vezes: de uma mulher e da fazenda. Duas mães e nenhum pai” (COETZEE, 2010, p. 89).

A relação com pai ao longo de todo o romance é conturbada e negada, isso também fica evidente na única foto em que o pai está presente em todo o acervo encontrado ${ }^{5}$. Nesse registro, vemos tia Annie com o dedo reprovador apontado a Jack e este com os braços cruzados e atento

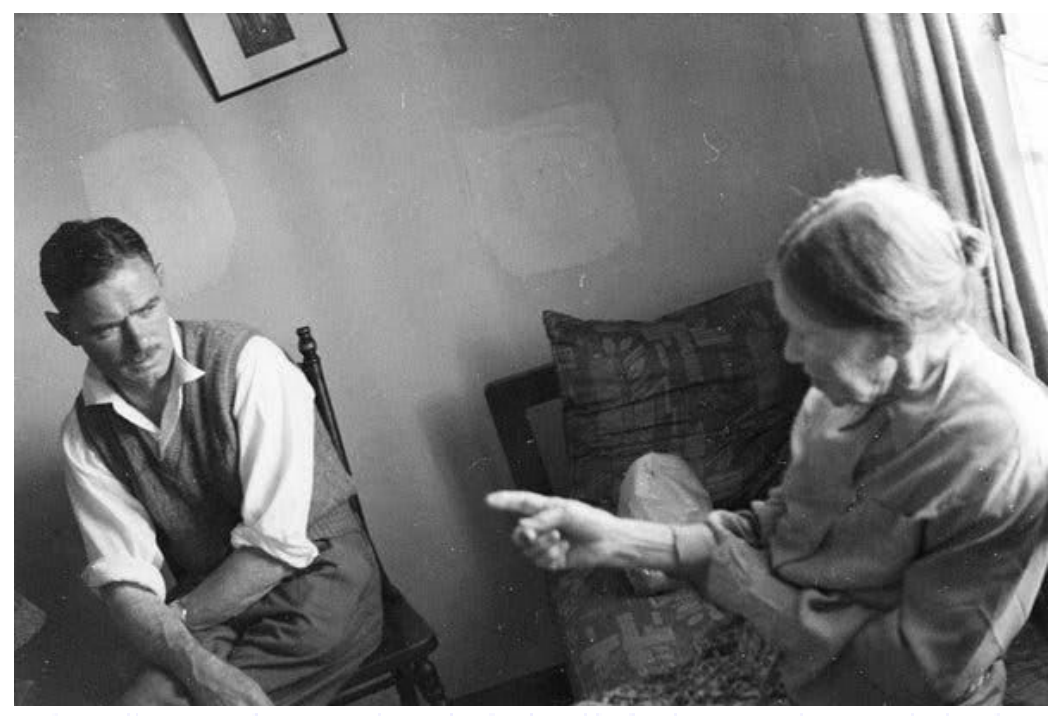

https://www_nytimes.com/2018/01/16/arts/design/coetzee-photographs.html

ao que a tia lhe fala.

"Ele sente raiva o tempo todo. Aquele homem, é como se refere ao pai quando fala com a mãe, com ódio demais para lhe chamar por um nome: por que temos alguma coisa a ver com aquele homem? Por que você não deixa aquele homem ir para a prisão?” (COETZEE, 2010, p. 143, grifos do autor). Nesse trecho, o uso do pronome demonstrativo "aquele" dá ainda mais

\footnotetext{
${ }^{5}$ Informação contida em https://www.nytimes.com/2018/01/16/arts/design/coetzee-photographs.html Acesso em jun. de 2019.
} 
destaque à relação entre pai e filho, pois intensifica a distância que há entre os dois. Esse afastamento também pode ser percebido na fotografia acima: o pai está em um segundo plano na imagem, além disso, está sendo recriminado pela tia Annie e possui, ainda, o corpo completamente fechado, braços e pernas cruzados. Em Infância, na maior parte da narrativa, a figura do pai é analisada externamente e sem nenhum tipo de complacência. Jack é submetido ao olhar cartesiano do narrador que expõe todos os erros cometidos pelo pai - quando este se envolve com dívidas - e chega ao extremo de desejar a morte do progenitor. "Com certeza não pode continuar dormindo. Seria possível que, maravilha das maravilhas, ele tenha cometido suicídio?" (COETZEE, 2010, p. 144). Em uma primeira leitura, o pai poderia ser o grande inimigo dessa narrativa, no entanto, segundo Cristovão Tezza, "chamar esse conjunto [Infância, Juventude e Verão] de 'Cenas da Vida na Província' é apenas um dos deslocamentos que Coetzee usa para avaliar a própria vida, com a qual parece manter uma difícil esgrima de busca de sentidos, contra um inimigo feroz - ele mesmo." Contudo, somos obrigados a perguntar: se o jovem Coetzee é o seu próprio inimigo quem seria o herói dessa narrativa? Para Vincent Colonna (2014), o escritor seria o herói de sua história, porém, numa acepção lógica, seria no mínimo absurdo pensar que a mesma personagem ocupa concomitantemente a posição de herói e vilão (ou inimigo) no mesmo texto literário. Entretanto, essa imagem construída do jovem Coetzee enquanto inimigo de si - é muito mais um fantasma de sua infância - talvez por isso o adulto Coetzee tenha feito questão de esquecer a caixa com as fotografias - do que alguém real.

Uma figura que o autor faz questão de rememorar tanto em Infância quanto em suas fotografias é a da mãe, Vera. No site onde estão algumas das fotografias encontradas no apartamento da Cidade do Cabo, há pelo menos quatro imagens da mãe:

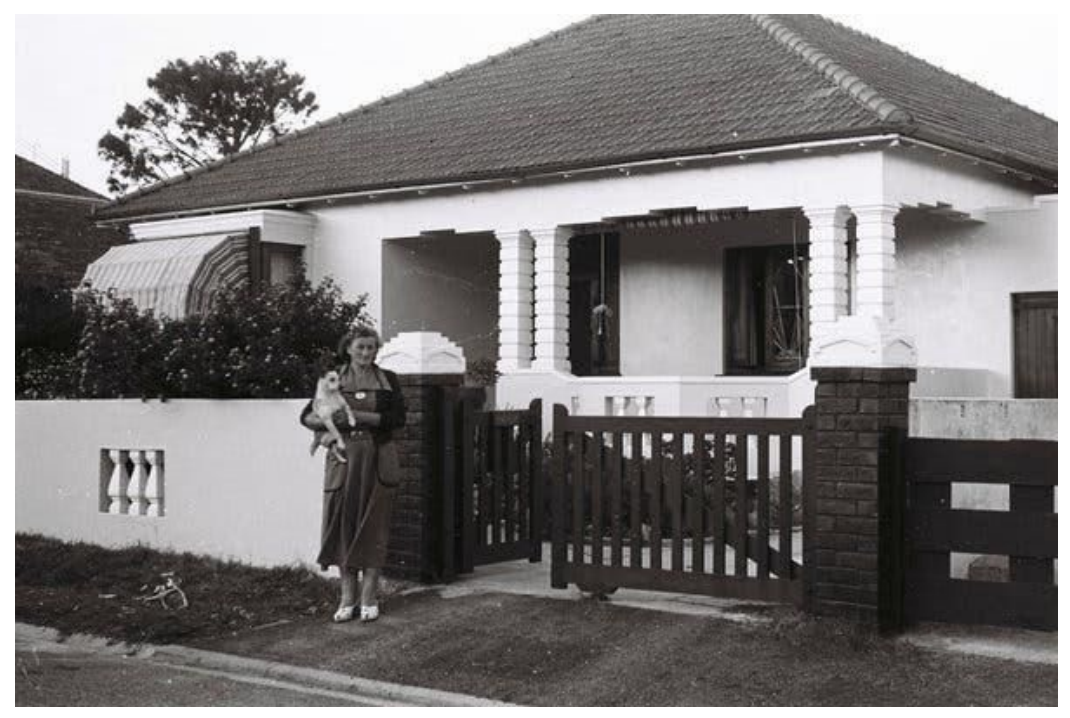


$\mathrm{Na}$ fotografia acima, vemos Vera em frente à casa, nos subúrbios da Cidade do Cabo, após o retorno da família de Worcester. A mãe era professora e ensinou inglês ao filho desde pequeno, sendo que esta se torna a primeira língua dele, apenas mais tarde aprenderá o africânder - língua do pai:

Essa mulher não foi trazida ao mundo com o único objetivo de amá-lo e protegê-lo e satisfazer as necessidades dele. Ao contrário, ela teve uma vida antes de ele existir, uma vida em que não havia a exigência de lhe dar atenção. Em certa época da vida ela o pariu; ela o pariu e decidiu amá-lo; talvez tenha decidido amá-lo antes mesmo de dar à luz; mas ela decidiu amá-lo e, portanto, pode decidir deixar de amá-lo. (COETZEE, 2010, p. 147).

O conceito de “amor" aqui é muito claro: é uma decisão. Quando a mãe é submetida ao microscópio do laboratório do escritor, ela é vista como uma mulher que teve uma criança e que por carregar aquele ser terá duas escolhas: decidir amá-la ou não. E da mesma forma quando ela é submetida à lente fotográfica do jovem Coetzee, a mãe é retratada lendo, deitada junto ao irmão ou - conforme a foto acima - na frente da casa com um cachorro em seus braços, ações que representam em alguma medida afeto. Ou seja, assim como o uso do pronome "essa" aproxima os dois na recordação acima, a mãe é muito mais próxima ao filho se compararmos ao pai. Ele se recorda dela sempre a partir de um amor inexiste nas relações com o pai. "Não pode imaginar que ela morra. Ela é a coisa mais sólida em sua vida. É o rochedo que o sustenta. Sem ela, ele não seria nada" (COETZEE, 2010, p. 35).

Tanto as fotografias quanto os textos aqui destacados tornam-se materializações da memória (RICOEUR, 2007) do fotógrafo-autor. Nas imagens, o olhar do fotógrafo nos direciona para as cenas do seu cotidiano, para as pessoas de sua família e convívio, para os lugares e objetos que são registrados pela sua lente. Já no texto literário, é um narrador extradiegético que nos conduz por esses mesmos caminhos capturados. Contudo, o ato de capturar uma cena pela fotografia - ainda mais na época em que elas foram tiradas - revela um desejo em guardar essas lembranças, os momentos da infância de Coetzee. Porém, o esquecimento da caixa com os negativos das fotos em um apartamento é contrário dentro dessa lógica. Por outro lado, o desejo do autor em escrever e publicar um livro que ao mesmo tempo registra essas mesmas cenas revela um carinho especial para esses anos infantis. Assim, os espaços vazios da memória são preenchidos pela imaginação na escrita do romance. Diferentemente da fotografia que não deixa 
espaços para possíveis e futuros complementos da anamnesis. Coetzee, desse modo, captura as suas memórias ao recordar no texto literário os momentos de sua infância. As fotografias nos surgem como possíveis afirmações e ilustrações acerca daquilo que o autor registra em sua “autoficção biográfica" (COLONNA, 2014). Em outras palavras, poderíamos dizer que o suposto "esquecimento" das fotografias se volta para um desejo - consciente ou inconsciente? - em deixar para trás a concretude dessas memórias - materializadas nas fotografias - e que agora são reescritas - materializadas pelo livro - e eivadas pela imaginação. Lemos no texto literário apenas aquilo que o escritor quer que o seu interlocutor leia, somos direcionados pelo seu narrador que enquanto mostra os locais e pessoas comenta e interfere livremente; mais uma vez, esse espaço para comentários e opiniões de uma voz narrativa, a fotografia não possui, pois, neste contexto, está próxima daquela concepção de memória enquanto mneme.

\section{Considerações finais}

A relação que tentamos estabelecer entre as fotografias e a narrativa de Coetzee nos permite questionar os desdobramentos da memória e os modos narrativos de rememoração. Um autor, seja em uma narrativa autobiográfica ou mesmo em um romance, faz escolhas do que apresentará ou não ao seu leitor. No entanto, Infância é marcado muito mais por aquilo que Coetzee resolveu esconder. Como nos trechos explicitados, ele recorda - ou ficcionaliza? detalhes minuciosos de sua meninice, contudo, em outros momentos diz não lembrar - ou esconder? "O que ele disse a Agnes naquela tarde, já não pode lembrar. Mas disse-lhe tudo, tudo mesmo, tudo o que sabia, tudo o que desejava. Ela ouviu tudo em silêncio. [...] Agnes usava apenas um vestido fino de algodão; seus pés estavam azulados de frio" (COETZEE, 2010, p. 87). Nesse sentido, é possível questionar: o que mais Coetzee escondeu de seu leitor? Quais outras caixas com registros fotográficos estariam escondidas?

A caixa mnemônica esquecida de Coetzee torna-se imagem, nesse contexto, de um aspecto da memória comum ao ser humano: aquelas lembranças que queremos esquecer e abandonar em um canto qualquer da mente. Quando essa caixa é descoberta, imagens nos são reapresentadas e a partir delas temos a opção de mostrá-las ou não. Da mesma maneira que a 
simples recordação, mais uma vez a reflexão recai sobre os itens encontrados e, com isso, muito se pode dizer e afirmar a respeito da memória. Tal como as outras três caixas que Aleida Assmann (2011) apresenta em seu texto, esta também é transportável e passível de desdobramentos concretos sobre os registros nela contidos. No entanto, não nos cabe questionar o que ainda não foi apresentado, enquanto leitores, estamos condicionados ao texto e à revelação de novas caixas mnemônicas. Mas a caixa esquecida da infância de Coetzee revela os registros, imagens e mesmo aquelas lembranças imateriais que fazemos questão de esconder ou deletar. No nível da memória cultural, poderíamos associar esta caixa a todos aqueles registros que foram esquecidos ou apagados das ditaduras, do nazismo e de revoluções de cunho opressor, pois poderiam revelar outros aspectos relativos à verdade e à memória social-cultural que foram esquecidos, ou melhor, foram deixados em um canto qualquer da memória para que não sejam rememorados.

\section{REFERÊNCIAS}

ASSMANN, Aleida. Espaços da recordação: formas e transformações da memória cultural. Trad. Paulo Soethe. Campinas, SP: Editora da Unicamp, 2011. BENJAMIN, Walter. A obra de arte na época de sua reprodutibilidade técnica. Trad. Francisco de Ambrosis Pinheiro Machado. Porto Alegre, RS: Zouk, 2014.

COETZEE, J. M. Infância: cenas da vida na província. Trad. Luiz Roberto Mendes Gonçalves. São Paulo: Companhia das Letras, 2010.

COLONNA, Vincent. Tipologia da autoficção. In: NORONHA, Jovita Maria Gerheim. (Org.) Ensaios sobre autoficção. Trad. Jovita Maria Gerheim Noronha e Maria Inês Coimbra Guedes. Belo Horizonte, MG: Editora UFMG, p. 39-66, 2014.

RICOEUR, Paul. A memória, a história, o esquecimento. Trad. Alain François et. al. Campinas, SP: Editora da Unicamp, 2007.

TEZZA, Cristovão. Inaptidão para a felicidade: a trilogia autobiográfica de J. M. Coetzee. Disponível em: $<\underline{\text { http://substantivoplural.com.br/tezza-escreve-sobre-a-trilogia-de-coetzee/>. }}$. Acesso em jun. de 2019.

Recebido em 07/09/2019. Aceito em 09/12/2019. 